\title{
DISTRIBUTION OF THE INVASIVE SPINY-CHEEK CRAYFISH (ORCONECTES LIMOSUS) IN THE CZECH REPUBLIC. PAST AND PRESENT
}

\author{
A. PETRUSEK (1), L. FILIPOVÁ (1), Z. ĎURIŠ (2), I. HORKÁ (2), P. KOZÁK (3),T. \\ POLICAR (3), M. ŠTAMBERGOVÁ (4), Z. KUČERA (4)
}

(1) Department of Ecology, Charles University, Viničná 7, Prague 2, CZ-12844, Czech Republic. E-Mail: petrusek@cesnet.cz

(2) Department of Biology, University of Ostrava, Chittussiho 10, Ostrava, CZ-71000, Czech Republic.

(3) University of South Bohemia in České Budějovice, Research Institute of Fish Culture and Hydrobiology at Vodňany, Zátiší 728/II, Vodňany, CZ-38925, Czech Republic.

(4) Agency for Nature Conservation and Landscape Protection of the Czech Republic, Kališnická 4-6, Prague 3, CZ-13000, Czech Republic.

Reçu le 23 juin 2005

Received June 23, 2005

Accepté le 30 décembre 2005

Accepted December 30, 2005

\begin{abstract}
The American spiny-cheek crayfish, Orconectes limosus, was first introduced into European waters in 1890 . The first literature record about the occurrence of $O$. limosus on the territory of the Czech Republic was published almost 100 years later - in 1989. The presence of this species in Czechia, however, was first recorded already in the 1960s, when crayfish were observed in the dead arms and pools adjacent to the river Elbe (Labe) in Central Bohemia. In the following few decades the spiny-cheek crayfish has spread into several larger rivers of the Elbe watershed and some of their smaller tributaries. The eastern part of the country (mostly belonging to the watershed of the river Morava) has not yet been colonised by this species. $O$. limosus can be found in lower reaches of a number of watercourses of a low stream order, but does not seem to penetrate far upstream in such localities. Its distribution in standing waters is largely the result of intentional humanmediated translocations. The long-term coexistence of Orconectes and native crayfish species has not yet been recorded, although both introduced and native crayfish at least occasionally come into contact. As $O$. limosus is a major carrier of the crayfish plague on the Czech territory, and crayfish plague outbreaks have been recently recorded, the dynamics of Orconectes invasion deserves careful monitoring in the future.
\end{abstract}

Key-words: Orconectes limosus, spiny cheek crayfish, invasive species, distribution, crayfish plague, Czech Republic. 


\section{DISTRIBUTION DE L'ÉCREVISSE INVASIVE (ORCONECTES LIMOSUS) EN RÉPUBLIQUE TCHĖQUE. PASSÉ ET PRÉSENT}

\section{RÉSUMÉ}

L'écrevisse américaine, Orconectes limosus, a été introduite en Europe en 1890. Les premiers écrits relatant la présence d'O. limosus sur le territoire de la République tchèque ont été publié presque 100 ans plus tard, en 1989. Cette espèce a déjà été observée en Tchéchie cependant, dans les années 60 , dans les bras morts et les plans d'eau adjacents à la rivière Elbe (Labe) en Bohème centrale. Dans les décennies suivantes, l'écrevisse américaine a colonisé d'autres grands cours d'eau du bassin de l'Elbe, et quelques-uns de leurs plus petits affluents. La partie orientale du pays (correspondant principalement au bassin de la rivière Morava) n'a pas encore été colonisée par cette espèce. $O$. limosus est présente dans les parties les plus basses d'un certain nombre de cours d'eau d'ordre hydrographique faible, mais elle ne semble pas remonter très en amont des cours d'eau. Sa répartition dans les eaux calmes est largement le résultat des transports effectués par I'homme. La coexistence au long-terme d'Orconectes et des espèces natives d'écrevisse n'a pas encore été établie, bien que les écrevisses natives et les écrevisses introduites se retrouvent au moins occasionnellement en contact. L'écrevisse O. limosus étant le principal vecteur de la peste de l'écrevisse sur le territoire tchèque, et des cas de peste de l'écrevisse ayant été récemment enregistrés, la dynamique de l'invasion de l'Orconectes doit être soigneusement suivie dans le futur.

Mots-clés : Orconectes limosus, écrevisse américaine, espèce invasive, distribution, peste de l'écrevisse, République Tchèque.

\section{INTRODUCTION}

The crayfish plague, caused by the oomycete Aphanomyces astaci, was accidentally introduced to Europe in the 1860's (VOGT, 1999). The disease quickly spread over a large part of European water bodies and the numbers of native crayfish were dramatically reduced. The attempts to replace the lost populations, and to substitute sensitive species with those resistant to the disease, led to a number of intentional introductions of nonnative crayfish to Europe (HENTTONEN and HUNER, 1999). The introduced species were Astacus leptodactylus (native to the eastern part of Europe and the Near East, sensitive to the plague) and the North American species Orconectes limosus, Pacifastacus leniusculus and Procambarus clarkii. The presence of non-native species on the continent caused, however, a number of unexpected additional problems. The crayfish from North America often carry the crayfish plague pathogen or other diseases and may transmit them to the native populations (VOGT, 1999). Therefore, with the spread of non-native species in recent decades, the crayfish plague outbreaks are again gaining in intensity $(\mathrm{HOLDICH}$, 2003).

Furthermore, the indigenous crayfish can also be displaced through direct interactions or competition for resources with the non-native species (HOLDICH, 1999). American crayfish are usually characterized by high growth rates, early maturity and large amounts of offspring, but also short life spans and high mortality rates. They are often aggressive and tolerate deteriorated habitat conditions (LINDQVIST and HUNER, 1999). Some of them (especially Procambarus clarkii, in Britain also Pacifastacus leniusculus) can cause large damages in agricultural and recreational areas by burrowing (HOLDICH, 1999).

Out of five species of crayfish present in the wild in Czechia (POLICAR and KOZÁK, 2000), only two are native: the noble crayfish, Astacus astacus, and the stone crayfish, Austropotamobius torrentium. Both of them are protected by law as critically endangered species. The rest of the crayfish species present in the country have been either 
intentionally introduced (Astacus leptodactylus, Pacifastacus leniusculus) or colonised the area naturally from another region (Orconectes limosus). The narrow-clawed crayfish, Astacus leptodactylus, was introduced to Czechia at the end of the $19^{\text {th }}$ century in order to replenish the reduced native populations of the noble crayfish. Since then, it became an integral part of the local fauna, and its populations are scattered all over the country (ĎURIŠ and HORKÁ, 2001).

The signal crayfish, Pacifastacus leniusculus, was brought to the Czech territory from Sweden in the 1980s for aquaculture purposes. Its acclimation at most localities was unsuccessful, but the population near the town Velké Meziríćí has established itself successfully and specimens from that area have been later transferred to several other places in the country (POLICAR and KOZÁK, 2000). The distribution of this species still remains restricted to only a few localities.

The most widespread non-native species in the Czech Republic is the spiny-cheek crayfish, Orconectes limosus. It was first intentionally introduced to Europe in 1890, when about 100 specimens from Pennsylvania were released to a fishpond in Barnowko (Berneuchen, Western Pommerania; currently in Poland close to the German border) (KOSSAKOWSKI, 1966; HAMR, 2002). In 1895, an additional but unsuccessful attempt was made to introduce this crayfish from New York to France (KOSSAKOWSKI, 1966). The original locality in Poland therefore seems to be the only source of Orconectes limosus populations on the European territory. Since the first introduction, this crayfish has spread naturally or by secondary translocations to over 15 European countries, including the Czech Republic and its neighbours - Poland, Germany, and Austria (HENTTONEN and HUNER, 1999; HOLDICH, 2003). Its presence in Slovakia has not been confirmed so far (STLOUKAL and HARVÁNEKOVÁ, 2005).

A brief overview of the distribution of Orconectes limosus in the Czech Republic has already been included in the study of KOZÁK et al. (2004); however, no detailed information on the localities was given. The aim of the present study is to summarise available records on the history of the invasion of Orconectes limosus on the territory of the Czech Republic, present up-to-date data on its current distribution, and analyse types of water bodies this species occupies.

\section{METHODS}

The review of the distribution of Orconectes limosus on the territory of the Czech Republic in the past (up to 2000) is based on available literature data, mostly published in local journals inaccessible to the international scientific community.

The present distribution of this species was assessed mainly from the long-term activities aimed at collecting data on the distribution of all crayfish species in the country. During the last five years, a number of localities with Orconectes presence reported in the past were repeatedly re-sampled.

Additionally, we present here the data on Orconectes limosus from an intensive mapping of crayfish distribution, which was carried out by the Agency for Nature Conservation and Landscape Protection of the Czech Republic in 2004-5. The mapping covered running waters in most of the country (over $90 \%$ of the surface area, and over $90 \%$ of all watercourses except of the smallest ones). Small to medium watercourses were examined for crayfish presence every 3 kilometres, starting $100 \mathrm{~m}$ above the confluence with the higher-order stream, and continuing upstream up to the stream source. At each locality, an approximately $100 \mathrm{~m}$ long stretch of the stream was inspected, and shelters suitable for crayfish were searched. Larger rivers were sampled every 4-7 kilometres (depending on the habitat suitability) using the baited traps. At least three traps containing fresh fish meat as bait were left overnight at each site, in a slow-flowing part of the river in 
deeper water close to the river bank. Traps were collected in the morning and checked for crayfish presence. Altogether, over 9,000 profiles on small streams, and over 350 on large rivers, were inspected during the mapping project.

We also used information provided by the general public (e.g. scuba divers) in cases when the identification of the species was unambiguous or photodocumentation was available. For each locality, we present the date (if available) or year(s) of observation and the character of the habitat (stagnant/running water, type of the water body). Additionally, we include the literature data on observations of this species from 2001 to present.

For populations from running waters, we calculated the distance from the mouth of the river/stream and the stream order, using the GIS data on the hydrological network of the Czech Republic (T.G.M. WRI Hydroecological Information System, http://heis.vuv. $\mathrm{cz}$ ). To be able to compare the position of localities and tributaries of the river Elbe, we use the distance from the German border rather than standard river kilometres, as there are several overlapping kilometric systems in use on the Czech stretch of this river. A distribution map, using a standard grid for faunistic mapping recommended for the territory of the Czech Republic (BUCHAR, 1982), was compiled using the data from all accessible sources. Recent records (after 2000) and pre-2000 historical localities with Orconectes not recorded later are distinguisher by colour.

\section{RESULTS}

\section{Historical data}

Published records of Orconectes limosus on the territory of the Czech Republic prior to 2001 are listed in Table I. The first effort to introduce this species to the region had been already made at the turn of the $20^{\text {th }}$ century but with no success (MATÉNA, 1995). Its presence was first reported in the literature by HAJER (1989). The spiny-cheek crayfish was repeatedly observed in the river Elbe (Labe) in the surroundings of the town Ústí nad Labem, approximately $40 \mathrm{~km}$ upstream from the German border, since at least the mid-1980s. By that time it had probably also penetrated to the river Bílina (left-side tributary of the Elbe). Between 1987 and 1988, the crayfish were also found in Čelákovice, $146 \mathrm{~km}$ upstream from the border (SAMEK, pers. comm.). Since then, the species has been recorded in a wide range of localities in the western part of the country (HAJER, 1990, 1994; BERAN, 1995, 2003; KOZÁK et al., 2004).

The spiny-cheek crayfish had most likely immigrated into the region naturally through the river Elbe (KOZÁK et al., 2004). It seems, however, that the Orconectes invasion had gone undetected for a long time. According to the record of an amateur fisherman (MATOUŠ, 1995), already in the 1960s small crayfish were present in high densities in dead arms and pools adjacent to the river near Štětí, about $80 \mathrm{~km}$ upstream from the border with Germany. The identity of these crayfish as $O$. limosus is beyond doubt for several reasons: the author described them as small (no more than $8 \mathrm{~cm}$ long) aggressive crayfish often exhibiting daytime activity, and these crayfish had been apparently able to tolerate heavily polluted water of the Elbe in the 1960s (MATOUŠ, 1995). Orconectes is still present in the same area (Tables I, II).

Following his first report on Orconectes presence in Czech waters, HAJER (1994) reported the occurrence of the spiny-cheek crayfish in a number of rivers of the Elbe watershed. The indicated populations were often located far from the confluence of the particular river with the Elbe or VItava (see Table l). The most significant are records of the presence of Orconectes in higher reaches of the rivers Ohře $(\mathrm{km} \mathrm{90)}$, Sázava $(\mathrm{km}$ 162), Berounka ( $k m$ 139) and its tributaries, or Vltava (km 240) (HAJER, 1994). Apart from the latter, the presence of $O$. limosus in such distant parts of these rivers has not been confirmed later. Such areas are marked in Figure 1 by open circles. 


\section{Present status}

The localities where Orconectes limosus was recorded since 2001 are listed in Table II, and shown in Figure 1. Although the list certainly does not include all water courses and bodies with the presence of this species on the territory of the Czech Republic, it gives a reasonable picture of the current distribution of the species. The spinycheek crayfish is mainly present in the western part of the country (Elbe watershed). The core of its distribution still remains in the river Elbe (including various adjacent oxbows and pools). It occurs in the whole navigable part of this river (which is almost completely canalised) from the border with Germany to the town Pardubice $(240 \mathrm{~km}$ from the German border) but probably in lower densities also further upstream. The population of $O$. limosus was recorded also in the town Jaroměr ( $289 \mathrm{~km}$ upstream from the border) in the Elbe and two of its tributaries (Úpa and Metuje). However, according to local fishermen as well as

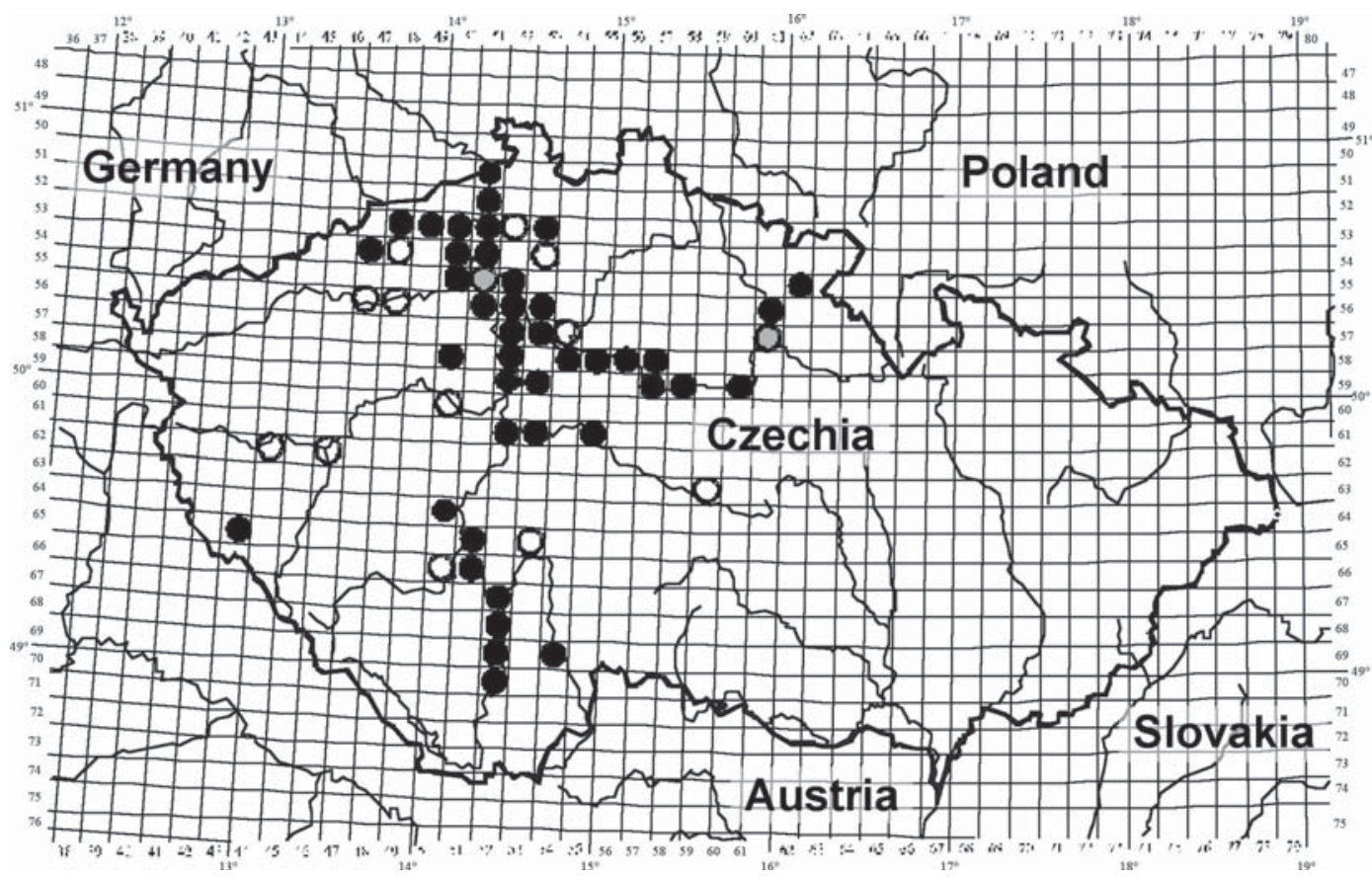

Figure 1

Currently known and previously recorded localities of Orconectes limosus marked on a standard grid used for the faunistic mapping in Czechia (each square corresponds to 10' of longitude and 6' of latitude, i.e. approx. $11 \times 11 \mathrm{~km}$ ).

black circle: presence in the square confirmed after 2000,

grey circle: historical record (up to 2000) with very likely continuous presence, open circle: records up to 2000 not confirmed later.

\section{Figure 1}

Sites de présence d'Orconectes limosus, passée ou actuelle, localisés sur une grille standard utilisée pour la cartographie faunistique en Tchéquie (chaque carré correspond à $10^{\prime}$ de longitude et $6^{\prime}$ de latitude, i.e. approximativement $11 \times 11 \mathrm{~km})$.

rond noir : présence dans le carré confirmée après 2000,

rond gris : présence ancienne (jusqu'à 2000) avec présence actuelle très vraisemblable, cercle vide : présence jusqu’à 2000, non confirmé ultérieurement. 
the river management authorities (ŠPAČEK, pers. comm.), the spiny-cheek crayfish had been intentionally stocked in this area.

Larger watercourses (of $6^{\text {th }}$ or higher stream order) with the certain presence of the spiny-cheek crayfish include Ohře, Vltava, Jizera, Mrlina, Cidlina, Doubrava, Metuje, and Úpa (all tributaries of the Elbe), and Otava, Lužnice, Sázava, and Malše (tributaries of the Vltava). The presence of this species may be presumed also in the Lomnice and other rivers and streams partially flooded by Vltava reservoirs, and in various larger tributaries of the Elbe.

In most of the above-mentioned rivers, the crayfish presence was confirmed in their lower reaches but recent data from upper reaches are lacking. The notable exceptions are: 1) the Vltava where the spiny-cheek crayfish is present in its lower part (from Prague downstream to the river Elbe), in several reservoirs in its middle section, and reaches upstream to the town České Budějovice (240 km from the confluence); 2) the Sázava, a tributary of the Vltava, where the crayfish seem to be present at least $50 \mathrm{~km}$ upstream from its confluence with the Vltava. Another such river is the Úpa in north-east Bohemia, with Orconectes over $30 \mathrm{~km}$ upstream from the Elbe. The latter case is known, however, to be a result of human introduction (ŠPAČEK, pers. comm.).

Orconectes limosus was found also in a number of smaller streams (i.e. those with a low stream order), which join larger rivers. In these cases the crayfish usually stay very close to the confluence with the major watercourse (less than $3 \mathrm{~km}$, usually only a few hundred meters), and do not penetrate far upstream. The relationship between the stream order and the maximum distance of recorded Orconectes presence from the stream mouth is shown in Figure 2. (In cases of small streams joining other watercourse first, the total distance to the nearest larger river with presumed or confirmed Orconectes presence was calculated.)

Additionally, this species is found in several standing waters. Some of them, especially flooded sandpits and quarries, have no surface inflow or outflow. Several other standing waters are connected to watercourses, and crayfish may penetrate into them. This has certainly happened at three places (the flooded surface coal mine Barbora and its ouflow; the mining water reservoirs Kateřina and Modlany and their connecting channel; and the large fishpond Velký rybník on the stream Pšovka). At some other places similar relationships between Orconectes populations in standing water bodies and adjacent streams may be suspected. All such cases belong among the exceptions where the spinycheek crayfish is present in a watercourse of a low stream order (1-4) relatively far (more than $10 \mathrm{~km}$ ) from the confluence with a major river. These cases are marked in Table II by "+" followed by a superscript numerical code, which identifies corresponding records from running and standing waters.

\section{DISCUSSION}

According to the results of the intensive mapping effort, the spiny-cheek crayfish on the territory of the Czech Republic is as yet present only in the Elbe watershed. The area drained by the Morava, covering most of the eastern part of the country, has not been colonised yet, nor the upper part of the watershed of the Odra (Oder), which extends into the Czech territory. There is a certain likelihood that the spiny-cheek crayfish may naturally reach lower reaches of the Morava by upstream migration from the Danube. Not only this species is present in the Danube in Austria (PÖCKL, 1999) and in Hungary where it is actively spreading (PUKY, 2000; PUKY et al., 2005), but it has been already sparsely found directly in the lower reaches of the Morava in Austria, approximately $30 \mathrm{~km}$ downstream from the Czech border (PÖCKL and PEKNY, 2002). Other potential sources from where this species might be transferred to the Morava watershed are located in watersheds of 
the Odra (Oder) and the Wisla (Vistula) in Poland (KOZÁK et al., 2004), or of the Elbe. In those cases the natural spread of the crayfish is unlikely as they would have to cross the watershed divide. However, the spiny-cheek crayfish may be stocked by humans intentionally or transferred unintentionally from any other locality.

The occurrence of this species in a number of isolated standing water bodies, especially flooded quarries or sandpits, is certainly, at least in some cases, caused by human-mediated translocations (especially by fishermen, recreational scuba divers etc., who admit to the stocking, being usually unaware of the potential danger of transferring nonindigenous species). Some populations present in running waters are also of anthropogenic origin. Apart from above-mentioned upstream section of the Elbe and its tributaries (Úpa, Metuje), one more recent case of crayfish stocking into a stream is confirmed (Drnovský stream, Central Bohemia; stocked in 2005 from a nearby village pond, most individuals were removed later during the year). Additionally, crayfish penetrate to inflows or outflows of standing waters, into which they may have been previously stocked artificially.

It is also possible that artificial stocking allowed this species to colonise reservoirs on the river VItava, as the distribution pattern in this river (Figure 1, southern part of the country) does not seem to confirm the natural upstream spread of crayfish, and the reservoir dams (some of them over $50 \mathrm{~m}$ high) are significant migration barriers.

Scuba divers are certainly responsible for stocking of the spiny-cheek crayfish into the flooded quarry "Na skále" near Starý Klíčov (Mrákov, western Bohemia), which is a popular diving site. Currently it is inhabited by a very dense population of O. limosus, which is even supplied food by the local diving club. Additionally, a single specimen of the noble crayfish Astacus astacus was recorded in the same locality in December 2002, and several individuals of the narrow-clawed crayfish Astacus leptodactylus were found there between December 2002 and November 2003 (KOZÁK, unpublished). This confirms that various crayfish had been illegally released to the quarry multiple times.

The quarry Klíčov contains an isolated population of Orconectes relatively far from other localities of this species, and it is situated only about $10 \mathrm{~km}$ away from a stream where a population of the critically endangered stone crayfish Austropotamobius torrentium is found (KOZÁK et al., 2002). The presence of Orconectes in the region is therefore highly undesirable, as there is a danger of potential transmission of the crayfish plague. The eradication of Orconectes population is virtually impossible; however, every effort should be made not to spread the species further.

Although Astacus spp. and Orconectes have been spotted at the above-mentioned locality, so far there is no evidence of the long-term coexistence of American and native species on the Czech territory - unlike some other countries where this was occasionally reported, e.g. in Finland where Astacus astacus and Pacifastacus leniusculus occurred in the same lake (NYLUND and WESTMAN, 2000) or in Austria, with O. limosus and $A$. leptodactylus in the same stretch of the river Morava (PÖCKL and PEKNY, 2002).

On the other hand, there is evidence for at least one case of crayfish plague transmission from Orconectes to the native species in recent years (KOZUBíKOVÁ et al., 2006). In the Pšovka brook (Central Bohemia, north of Prague) three crayfish species were found in the 1990s, each of them in a different part of the river - Orconectes limosus in the lower reach, Astacus leptodactylus further upstream and the native Astacus astacus in higher reaches of this brook (BERAN, 1995). According to a local fisherman, the spinycheek crayfish had been intentionally stocked to the fishpond Velký rybník near Střemy. An outbreak of a disease with typical crayfish plague symptoms in 1998-1999 practically eradicated the populations of both Astacus species but did not affect Orconectes. The spiny-cheek crayfish is still abundant in the brook, and the presence of the crayfish plague pathogen Aphanomyces astaci was detected in several specimens (KOZUBÍKOVÁ et al., 2006). 
Additional evidence of the presence of Astacus astacus and Orconectes limosus in the same water body is in the reservoir Orlík on the river Vltava. The American species is rather abundant in the reservoir but a specimen of the noble crayfish burrowing in the mud in the depth of several meters was photographed by a scuba diver in October 2003 (PETRUSEK, unpublished). However, it is not possible to conclude for how long such a coexistence may have lasted.

Czech populations of Orconectes limosus seem to be widely infected by the crayfish plague pathogen (KOZUBÍKOVÁ et al., 2006). Fortunately, the fact that the species does not seem to penetrate far upstream in small watercourses may protect some populations of native species ( $A$. astacus and especially Austropotamobius torrentium) from the transmission of the plague by direct contact with its carriers. This is especially important, for example, for the Central Bohemian population of $A$. torrentium, which is present approximately $11 \mathrm{~km}$ upstream from the mouth of a stream directly joining an Orconectesinhabited section of the river Elbe. A similar situation has also been recorded in Hungary in the streams of the Danube Bend region (PUKY and SCHÁD, 2006).

The limited ability of $O$. limosus to penetrate into small streams can be documented by the fact that in spite of an intensive monitoring effort, records of this species from streams up to the $5^{\text {th }}$ stream order are usually limited to less than three kilometres from their confluence with a larger river (Figure 2, Table II). All exceptions from this pattern can be associated with a potential source population in a close-by standing water connected to the watercourse, or are known to be originally stocked by humans (indicated in Table II and Figure 2),

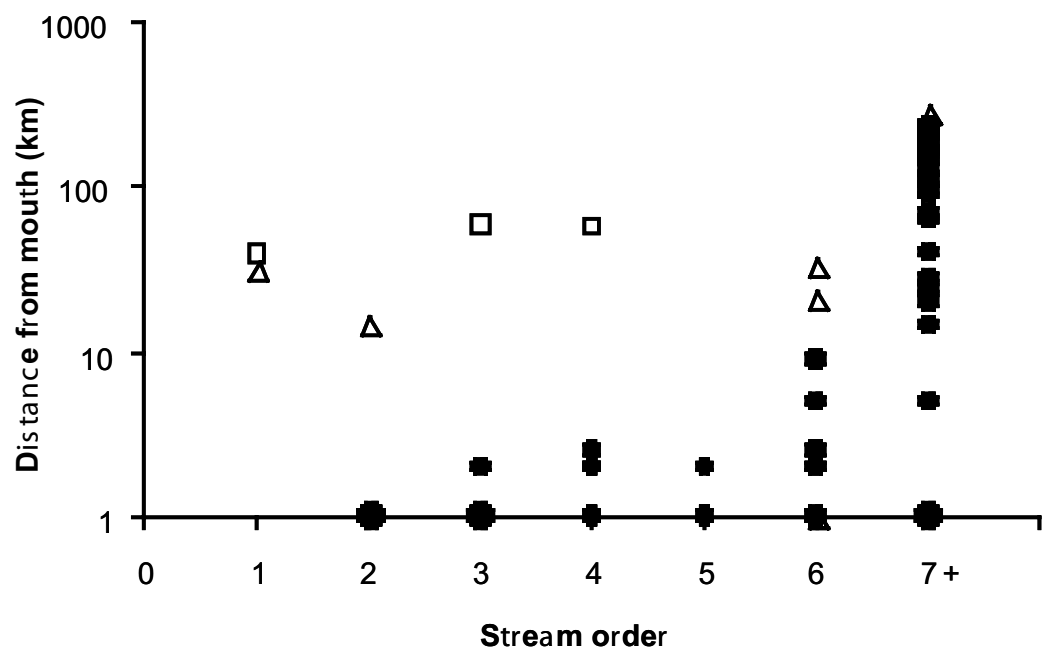

Figure 2

The relationship between the stream order and the distance of recent Czech Orconectes populations from the stream mouth (or nearest larger watercourse with presumed or confirmed presence of the species); the distance from the German border is used for the river Elbe. Large dots represent four or more sites. Populations originating with certainty from human stocking are marked by triangles, those spreading from adjacent standing waters by squares.

Figure 2

Relation entre l'ordre du cours d'eau et la distance des populations récentes d'Orconectes de l'embouchure du cours d'eau (ou du grand cours d'eau le plus proche avec présence supposée ou confirmée de l'espèce); la distance à la frontière allemande est utilisée pour l'Elbe. Les gros points représentent 4 sites ou plus. Les populations introduites avec certitude par l'homme sont indiquées par des triangles; celles qui se sont propagées à partir de plans d'eaux adjacents sont indiquées par des carrés. 


\section{Table I}

Data on the presence of Orconectes limosus in the Czech streams and water bodies up to 2000. The river kilometres are given from the mouth, in case of the Elbe (Labe) from the border with Germany.

Parentheses after the name of a watercourse give the name of the river which it joins (marked by an arrow), and the river kilometre where the confluence is located. The sources are abbreviated as follows: H89, H90, H94 - HAJER, 1989, 1990, 1994; B95, B03 - BERAN, 1995, 2003; B06 - BERAN, in press; M95 - MATĚNA, 1995; AOPK - archive of the Agency for Nature Conservation and Landscape Protection, ZD - unpublished data of Z. Duriš.

\section{Tableau I}

Données sur la présence d'Orconectes limosus dans les rivières et les plans d'eau tchèques jusqu'en 2000. Les "kilomètres-rivière " sont indiqués depuis l'embouchure, et dans le cas de l'Elbe depuis la frontière avec l'Allemagne.

Entre parenthèses après le nom des cours d'eau sont indiqués les noms des cours d'eau dans lesquels ils se jettent (repérés par une flèche), et le kilomètre rivière de la confluence. Les références bibliographiques sont abrégées comme suit: H89, H90, H94 - HAJER, 1989, 1990, 1994 ; B95, B03 - BERAN, 1995, 2003; B06 - BERAN, sous presse; M95 - MATĚNA, 1995; AOPK - archive de l'agence pour la conservation de la nature et la protection des Paysages, ZD - données non publiées de Z. Ďuriš.

\section{Table II}

Localities where the presence of Orconectes limosus in the Czech Republic was recorded or reconfirmed between 2000 and 2005. River kilometres are given as in Table I, the value in parentheses gives the effective distance to the nearest watercourse with presumed or confirmed presence of $O$. limosus.

The column "source" refers either to initials of one of the authors (AP, LF, ZD, PK, TP, MS), literature data (V03 - VRZAL, 2003; B03 - BERAN, 2003; B06 - BERAN, in press), unpublished records of Luboš Beran (LB), data of the Czech Union for Nature Conservation from Nymburk (CSOP), mapping programme of the Agency for Nature Conservation and Landscape Protection (AOPK), or to reliable personal communications by those listed. An asterisk in the "distance from mouth" column indicates a population with known origin by human stocking, "+" followed by a number in superscript after the locality name indicates potential source populations in standing waters and the corresponding records of Orconectes in running waters.

\section{Tableau II}

Sites où la présence d'Orconectes limosus en République tchèque a été notée ou confirmée entre 2000 et 2005. Les "kilomètres-rivière " sont indiqués comme dans le tableau I, les valeurs entre parenthèses donnent la distance effective au cours d'eau le plus près où la présence d'O. limosus est supposée ou confirmée.

Les données de la colonne "source" se réfèrent soit aux initiales abrégées de l'un des auteurs (AP, LF, ZD, PK, TP, MS), à des données de la littérature (V03 - VRZAL, 2003; B03 - BERAN, 2003; B06 - BERAN, in press), aux travaux non publiés de Luboš Beran (LB), aux données de l'Union tchèque pour la Conservation de la Nature de Nymburk (CSOP), aux données du programme de cartographie de l'Agence pour la Conservation de la Nature et de la Protection des Paysages (AOPK), ou à des communications personnelles fiables des auteurs listés. Un astérisque dans la colonne "distance à l'embouchure » indiquent que la population a été avec certitude introduite par l'homme, « + suivi par un nombre en exposé après le nom du site signale les populations potentielles d'origine dans les eaux calmes, et les populations correspondantes d'Orconectes dans les eaux courantes. 
Tableau I

\begin{tabular}{|c|c|c|c|c|c|c|c|}
\hline Watercourse / body & Nearest settlement & $\begin{array}{l}\text { Latitude } \\
\text { (N) }\end{array}$ & \begin{tabular}{|c|}
$\begin{array}{c}\text { Longitude } \\
\text { (E) }\end{array}$
\end{tabular} & \begin{tabular}{|c|} 
Date of \\
observation
\end{tabular} & $\begin{array}{c}\text { Stream } \\
\text { order }\end{array}$ & $\begin{array}{l}\text { Distance from } \\
\text { mouth }(\mathbf{k m})\end{array}$ & Source \\
\hline \multicolumn{8}{|c|}{ Labe (Elbe): between Ústí nad Labem and Pardubice canalised (slow flow or standing), distances calculated from the border with Germany } \\
\hline Labe & Hřensko & $50^{\circ} 52^{\prime}$ & $14^{\circ} 14^{\prime}$ & pre-1995 & 8 & 1 & M95 \\
\hline Labe & Děčín & $50^{\circ} 46^{\prime}$ & $14^{\circ} 13^{\prime}$ & $1991-2$ & 8 & 15 & H94 \\
\hline Labe & Ústí nad Labem & $50^{\circ} 39^{\prime}$ & $14^{\circ} 03^{\prime}$ & $1988-92$ & 8 & 38 & $\mathrm{H} 89, \mathrm{H} 94$ \\
\hline Labe & Brná nad Labem & $50^{\circ} 37^{\prime}$ & $14^{\circ} 05^{\prime}$ & 7.-9.05.88 & 8 & 43 & $\mathrm{H} 89, \mathrm{H} 90$ \\
\hline Labe & Litoměřice & $50^{\circ} 32^{\prime}$ & $14^{\circ} 08^{\prime}$ & $1991-2$ & 8 & 65 & $\mathrm{H} 94$ \\
\hline Labe & Roudnice & $50^{\circ} 26^{\prime}$ & $14^{\circ} 16^{\prime}$ & $1991-2$ & 8 & 82 & $\mathrm{H} 94$ \\
\hline Labe & Račice & $50^{\circ} 30^{\prime}$ & $14^{\circ} 22^{\prime}$ & $1991-2$ & 8 & 93 & $\mathrm{H} 94$ \\
\hline Labe & Mělník & $50^{\circ} 22^{\prime}$ & $14^{\circ} 28^{\prime}$ & $1991-2$ & 8 & 109 & $\mathrm{H} 94$ \\
\hline Labe (adjacent pools) & Křivenice & $50^{\circ} 25^{\prime}$ & $14^{\circ} 25^{\prime}$ & $05 / 06 / 98$ & 8 & 100 & $\mathrm{~B} 03$ \\
\hline Labe & Neratovice & $50^{\circ} 16^{\prime}$ & $14^{\circ} 32^{\prime}$ & $1991-2$ & 7 & 122 & $\mathrm{H} 94$ \\
\hline Labe & Čelákovice & $50^{\circ} 10^{\prime}$ & $14^{\circ} 45^{\prime}$ & pre-1995 & 7 & 146 & M95 \\
\hline Labe & Nymburk & $50^{\circ} 11^{\prime}$ & $15^{\circ} 03^{\prime}$ & $1991-2$ & 7 & 168 & $\mathrm{H} 94$ \\
\hline Labe & Poděbrady & $50^{\circ} 08^{\prime}$ & $15^{\circ} 07^{\prime}$ & $1991-2$ & 7 & 176 & $\mathrm{H} 94$ \\
\hline Labe & Pardubice & $50^{\circ} 03^{\prime}$ & $15^{\circ} 46^{\prime}$ & $1991-2$ & 7 & 240 & $\mathrm{H} 94$ \\
\hline Labe & Hradec Králové & $50^{\circ} 12^{\prime}$ & $15^{\circ} 49^{\prime}$ & $1991-2$ & 7 & 268 & $\mathrm{H} 94$ \\
\hline \multicolumn{8}{|c|}{ tributaries in the watershed of Elbe: running waters } \\
\hline Ploučnice $(\rightarrow$ Elbe, km 14) & Benešov nad Ploučnicí & $50^{\circ} 44^{\prime}$ & $14^{\circ} 19^{\prime}$ & $24 / 05 / 91$ & 6 & 11 & H94 \\
\hline $\begin{array}{l}\text { Dolský potok ( } \rightarrow \text { Fojtovický p., } \\
\text { km 0.5; } \rightarrow \text { Ploučnice, km 12; } \\
\rightarrow \text { Elbe, km 14) }\end{array}$ & Heřmanov & $50^{\circ} 44^{\prime}$ & $14^{\circ} 18^{\prime}$ & 1991 & 2 & $<1 ?$ & H94 \\
\hline Luční potok ( $\rightarrow$ Elbe, km 28 ) & Malé Březno & $50^{\circ} 40^{\prime}$ & $14^{\circ} 10^{\prime}$ & $1991-2$ & 4 & $<1$ & H94 \\
\hline Homolský potok ( $\rightarrow$ Elbe, km 30) & Velké Březno & $50^{\circ} 40^{\prime}$ & $14^{\circ} 08^{\prime}$ & $1991-2$ & 3 & $<1$ & $\mathrm{H} 94$ \\
\hline Bílina $(\rightarrow$ Elbe, $\mathrm{km} 39)$ & Bílina, & $50^{\circ} 33^{\prime}$ & $14^{\circ} 46^{\prime}$ & $1990 ?$ & 6 & $<5$ & $\mathrm{H} 90$ \\
\hline Bílina & $\begin{array}{l}\text { Bílina, confluence with } \\
\text { Syčivka }\end{array}$ & $50^{\circ} 33^{\prime}$ & $14^{\circ} 46^{\prime}$ & $29 / 05 / 91$ & 6 & 36 & H94 \\
\hline Průčelský potok $(\rightarrow$ Elbe, $\mathrm{km} 43)$ & Brná nad Labem & $50^{\circ} 37^{\prime}$ & $14^{\circ} 05^{\prime}$ & May 1988 & 2 & $<1$ & $\mathrm{H} 90$ \\
\hline Tlučenský potok ( $\rightarrow$ Elbe, km 47) & Sebuzín & $50^{\circ} 36^{\prime}$ & $14^{\circ} 05^{\prime}$ & $1991-2$ & 2 & $<1$ & $\mathrm{H} 94$ \\
\hline Ohře $(\rightarrow$ Elbe, $\mathrm{km} 65)$ & Litoměřice & $50^{\circ} 32^{\prime}$ & $14^{\circ} 08^{\prime}$ & $1991-2$ & 6 & $<1$ & $\mathrm{H} 94$ \\
\hline Ohře & Terezín & $50^{\circ} 31^{\prime}$ & $14^{\circ} 09^{\prime}$ & $14 / 07 / 97$ & 6 & 3 & B03 \\
\hline Ohře & Bohušovice nad Ohří & $50^{\circ} 30^{\prime}$ & $14^{\circ} 09^{\prime}$ & 1992,1997 & 6 & 5 & H94, B03 \\
\hline Ohře and its dead arm & Doksany & $50^{\circ} 27^{\prime}$ & $14^{\circ} 10^{\prime}$ & 2000 & 6 & 9 & B03 \\
\hline Ohře & Budyně nad Ohří & $50^{\circ} 25^{\prime}$ & $14^{\circ} 07^{\prime}$ & $05 / 06 / 91$ & 6 & 18 & $\mathrm{H} 94$ \\
\hline Ohře & Louny & $50^{\circ} 22^{\prime}$ & $13^{\circ} 48^{\prime}$ & $11 / 05 / 92$ & 6 & 54 & $\mathrm{H} 94$ \\
\hline Ohře & Žatec & $50^{\circ} 20^{\prime}$ & $13^{\circ} 33^{\prime}$ & $1991-2$ & 6 & 90 & $\mathrm{H} 94$ \\
\hline Pšovka ( $\rightarrow$ Elbe, km 107) & Střemy & $50^{\circ} 23^{\prime}$ & $14^{\circ} 33^{\prime}$ & $1994-8$ & 2 & $14-15$ & B95, B06 \\
\hline Jizera $(\rightarrow$ Elbe, $\mathrm{km} 141)$ & Benátky nad Jizerou & $50^{\circ} 17^{\prime}$ & $14^{\circ} 50^{\prime}$ & $20 / 10 / 91$ & 6 & 20 & $\mathrm{H} 94$ \\
\hline Orlice $(\rightarrow$ Elbe, $\mathrm{km} 268)$ & Hradec Králové & $50^{\circ} 12^{\prime}$ & $15^{\circ} 49^{\prime}$ & $02 / 11 / 92$ & 6 & $<1$ & H94 \\
\hline \multicolumn{8}{|c|}{ river Vltava ( $\rightarrow$ Elbe, $109 \mathrm{~km}$ ): conditions vary from running to standing water (headwaters of weirs, reservoirs) } \\
\hline VItava & Mělník & $50^{\circ} 21^{\prime}$ & $14^{\circ} 29^{\prime}$ & 1991,1999 & 8 & $<1$ & H94, B03 \\
\hline Vltava & Vepřek & $50^{\circ} 18^{\prime}$ & $14^{\circ} 20^{\prime}$ & $20 / 06 / 98$ & 8 & 14 & B03 \\
\hline Vltava & Kralupy & $50^{\circ} 15^{\prime}$ & $14^{\circ} 19^{\prime}$ & $11 / 05 / 91$ & 8 & 22 & $\mathrm{H} 94$ \\
\hline Vltava & Praha (Prague) & $50^{\circ} 07^{\prime}$ & $14^{\circ} 28^{\prime}$ & \begin{tabular}{|c|}
$1991-2$ \\
$1998-9,2000$ \\
\end{tabular} & 8 & 47 & $\begin{array}{c}\mathrm{H} 94, \\
\text { P00, B05 }\end{array}$ \\
\hline Vltava (reservoir Orlík) & not specified & $\sim 49.5^{\circ}$ & $\sim 14^{\circ}$ & \begin{tabular}{|c|}
1994, \\
$1998-9,2000$
\end{tabular} & 8 & $145-180$ & $\begin{array}{c}\mathrm{M} 95, \\
\mathrm{P} 00, \mathrm{H} 00\end{array}$ \\
\hline VItava (reservoir Kořensko) & not specified & $\sim 49.2^{\circ}$ & $\sim 14.4^{\circ}$ & $1994,1998-9$ & $7-8$ & $200-209$ & M95, P00 \\
\hline VItava (reservoir Hněvkovice) & not specified & $\sim 49^{\circ}$ & $\sim 14.5^{\circ}$ & 1994 & 7 & $210-225$ & M95 \\
\hline Vltava & České Budějovice & $49^{\circ} 58^{\prime}$ & $14^{\circ} 28^{\prime}$ & $26 / 10 / 92$ & 7 & 240 & H94 \\
\hline \multicolumn{8}{|c|}{ tributaries in the watershed of VItava: mostly running waters } \\
\hline Berounka $(\rightarrow$ Vltava, km 63) & Beroun & $49^{\circ} 58^{\prime}$ & $14^{\circ} 05^{\prime}$ & $14 / 10 / 92$ & 7 & 35 & $\mathrm{H} 94$ \\
\hline Berounka & Plzeň & $49^{\circ} 45^{\prime}$ & $13^{\circ} 23^{\prime}$ & $27 / 10 / 91$ & 7 & 139 & $\mathrm{H} 94$ \\
\hline Úslava $(\rightarrow$ Berounka, $\mathrm{km} 136)$ & Plzeň & $49^{\circ} 45^{\prime}$ & $13^{\circ} 24^{\prime}$ & $27 / 10 / 91$ & 5 & $<5$ & $\mathrm{H} 94$ \\
\hline Mže $(\rightarrow$ Berounka, $\mathrm{km} \mathrm{139})$ & Plzeň & $49^{\circ} 45^{\prime}$ & $13^{\circ} 22^{\prime}$ & $27 / 10 / 91$ & 6 & $<5$ & $\mathrm{H} 94$ \\
\hline Mže (reservoir Hracholusky) & Plešnice & $49^{\circ} 47^{\prime}$ & $13^{\circ} 09^{\prime}$ & 1999 & reservoir & 24 & AOPK \\
\hline Radbuza ( $\rightarrow$ Berounka, km 139) & Plzeň & $49^{\circ} 43^{\prime}$ & $13^{\circ} 23^{\prime}$ & $27 / 10 / 91$ & 6 & $<5$ & $\mathrm{H} 94$ \\
\hline Úhlava $(\rightarrow$ Radbuza, km 5) & Plzeň & $49^{\circ} 45^{\prime}$ & $13^{\circ} 23^{\prime}$ & $27 / 10 / 91$ & 6 & $<5$ & $\mathrm{H} 94$ \\
\hline Sázava $(\rightarrow$ Vltava, km 78$)$ & Havlíčkův Brod & $49^{\circ} 36^{\prime}$ & $15^{\circ} 35^{\prime}$ & $15 / 10 / 92$ & 6 & 162 & $\mathrm{H} 94$ \\
\hline Otava $(\rightarrow$ Vltava, km 169) & Písek & $49^{\circ} 18^{\prime}$ & $14^{\circ} 08^{\prime}$ & $26 / 10 / 91$ & 7 & 26 & $\mathrm{H} 94$ \\
\hline Lužnice ( $\rightarrow$ Vltava, km 202) & Bechyně & $49^{\circ} 17^{\prime}$ & $14^{\circ} 28^{\prime}$ & 1992 & 7 & 11 & M95 \\
\hline Lužnice & Tábor & $49^{\circ} 25^{\prime}$ & $14^{\circ} 40^{\prime}$ & $02 / 09 / 92$ & 7 & 40 & $\mathrm{H} 94$ \\
\hline Malše $(\rightarrow$ Vltava, km 240) & České Budějovice & $49^{\circ} 58^{\prime}$ & $14^{\circ} 28^{\prime}$ & $16 / 07 / 92$ & 6 & $<1$ & H94 \\
\hline \multicolumn{5}{|l|}{ other standing waters } & \multicolumn{2}{|c|}{ character of the locality } & \\
\hline sandpit Lhota & Lhota & $50^{\circ} 15^{\prime}$ & $14^{\circ} 40^{\prime}$ & $12 / 07 / 97$ & sandpit & & B05 \\
\hline Proboštský rybník + other sandpits & Stará Boleslav & $50^{\circ} 12^{\prime}$ & $14^{\circ} 39^{\prime}$ & $01 / 05 / 95$ & sandpit & & B05 \\
\hline sandpit Ovčáry & Ovčáry & $50^{\circ} 15^{\prime}$ & $14^{\circ} 37^{\prime}$ & $23 / 04 / 95$ & sandpit & & ZD \\
\hline Klíčov (quarry "Na skále") & Mrákov & $49^{\circ} 24^{\prime}$ & $12^{\circ} 58^{\prime}$ & 1998 & flooded qua & & ZD \\
\hline Máchovo jezero & Doksy & $50^{\circ} 35^{\prime}$ & $14^{\circ} 39^{\prime}$ & $1991-2$ & fishpond & & $\mathrm{H} 94$ \\
\hline unspecified fishponds & Česká Lípa (region) & $\sim 50.5^{\circ}$ & $\sim 14.5^{\circ}$ & $1991-2$ & fishponds & & $\mathrm{H} 94$ \\
\hline pools and oxbows by the Elbe & Central to North Bohemia & wide area & & $1991-2$ & pools, dead & arms & H94 \\
\hline
\end{tabular}


Tableau II

\begin{tabular}{|c|c|c|c|c|c|c|c|}
\hline Watercourse / body & Nearest settlement & $\begin{array}{l}\text { Latitude } \\
\text { (N) }\end{array}$ & \begin{tabular}{|c|} 
Longitude \\
(E)
\end{tabular} & \begin{tabular}{|c|} 
Date of \\
observation
\end{tabular} & $\begin{array}{c}\text { Stream } \\
\text { order }\end{array}$ & $\begin{array}{l}\text { Distance from } \\
\text { mouth }(\mathbf{k m})\end{array}$ & Source \\
\hline \multicolumn{8}{|c|}{ Labe (Elbe): between Ústí nad Labem and Pardubice canalised (slow flow or standing), distances calculated from the border with Germany } \\
\hline Labe & Hřensko & $50^{\circ} 52^{\prime}$ & $14^{\circ} 14^{\prime}$ & $2001-4$ & 8 & 1 & J. Špaček \\
\hline Labe & Děčín & $50^{\circ} 47^{\prime}$ & $14^{\circ} 12^{\prime}$ & $08 / 09 / 05$ & 8 & 15 & LF \\
\hline Labe & Nebočady & $50^{\circ} 43^{\prime}$ & $14^{\circ} 11^{\prime}$ & $02 / 07 / 03$ & 8 & 20 & $\overline{Z D}$ \\
\hline Labe & Těchlovice & $50^{\circ} 42^{\prime}$ & $14^{\circ} 12^{\prime}$ & $02 / 07 / 03$ & 8 & 24 & ZD \\
\hline Labe & Malé Březno & $50^{\circ} 40^{\prime}$ & $14^{\circ} 10^{\prime}$ & $16 / 07 / 03$ & 8 & 28 & ZD \\
\hline Labe & Ústí nad Labem (Střekov) & $50^{\circ} 39^{\prime}$ & $14^{\circ} 03^{\prime}$ & $02 / 07 / 03$ & 8 & 40 & ZD \\
\hline Labe & Litoměřice & $50^{\circ} 32^{\prime}$ & $14^{\circ} 09^{\prime}$ & $2002-3$ & 8 & 64 & $\mathrm{~B} 05, \mathrm{ZD}$ \\
\hline $\begin{array}{l}\text { Labe } \\
\text { (confluence with Luční potok) }\end{array}$ & Třeboutice & $50^{\circ} 31^{\prime}$ & $14^{\circ} 12^{\prime}$ & 03/07/03 & 8 & 69 & ZD \\
\hline Labe & Štětí & $50^{\circ} 27^{\prime}$ & $14^{\circ} 22^{\prime}$ & $03 / 07 / 03$ & 8 & 94 & ZD \\
\hline Labe & Hněvice & $50^{\circ} 27^{\prime}$ & $14^{\circ} 22^{\prime}$ & $01 / 10 / 04$ & 8 & 95 & ZD \\
\hline Labe & Mělník & $50^{\circ} 22^{\prime}$ & $14^{\circ} 28^{\prime}$ & $13 / 09 / 04$ & 7 & 108 & $\mathrm{MS}$ \\
\hline Labe & Obríiství & $50^{\circ} 18^{\prime}$ & $14^{\circ} 29^{\prime}$ & $2001-5$ & 7 & 115 & ZD, PK, LF \\
\hline Labe & Kostelec nad Labem (Jiřice) & $50^{\circ} 14^{\prime}$ & $14^{\circ} 34^{\prime}$ & $22 / 05 / 04$ & 7 & 126 & ZD \\
\hline Labe & Brandýs nad Labem & $50^{\circ} 11^{\prime}$ & $14^{\circ} 40^{\prime}$ & $03 / 10 / 04$ & 7 & 136 & LB \\
\hline Labe & Čelákovice & $50^{\circ} 10^{\prime}$ & $14^{\circ} 45^{\prime}$ & $2001-4$ & 7 & 146 & $\mathrm{AP}$ \\
\hline $\begin{array}{l}\text { Labe } \\
\text { (confluence with Farský potok) }\end{array}$ & Ostrá & $50^{\circ} 10^{\prime}$ & $14^{\circ} 54^{\prime}$ & $22 / 05 / 04$ & 7 & 155 & ZD \\
\hline Labe & Hradištko & $50^{\circ} 10^{\prime}$ & $14^{\circ} 56^{\prime}$ & 2001,2005 & 7 & 159 & ZD, LF \\
\hline Labe & Nymburk & $50^{\circ} 11^{\prime}$ & $15^{\circ} 03^{\prime}$ & 2002 & 7 & 168 & CSOP \\
\hline Labe & Poděbrady & $50^{\circ} 09^{\prime}$ & $15^{\circ} 06^{\prime}$ & $09 / 10 / 03$ & 7 & 176 & ZD \\
\hline Labe & Kolín & $50^{\circ} 02^{\prime}$ & $15^{\circ} 13^{\prime}$ & $04 / 07 / 03$ & 7 & 193 & ZD \\
\hline Labe & Týnec nad Labem & $50^{\circ} 02^{\prime}$ & $15^{\circ} 22^{\prime}$ & $20 / 04 / 02$ & 7 & 205 & B05 \\
\hline Labe & Valy & $50^{\circ} 02^{\prime}$ & $15^{\circ} 37^{\prime}$ & $06 / 09 / 05$ & 7 & 227 & $\mathrm{LF}$ \\
\hline Labe & Pardubice & $50^{\circ} 03^{\prime}$ & $15^{\circ} 46^{\prime}$ & $2003-2005$ & 7 & $239-241$ & ZD, LB \\
\hline Labe & Jaroměř & $50^{\circ} 03^{\prime}$ & $15^{\circ} 46^{\prime}$ & 2004 & 7 & $287^{*}$ & J. Špaček \\
\hline \multicolumn{8}{|c|}{ tributaries of the river Elbe: running waters } \\
\hline Kamenička $(\rightarrow$ Elbe, km 10) & Boletice nad Labem & $50^{\circ} 45^{\prime}$ & $14^{\circ} 11^{\prime}$ & $17 / 09 / 05$ & 3 & $<1$ & AOPK \\
\hline Poustka $(\rightarrow$ Elbe, $\mathrm{km} \mathrm{18)}$ & Dobkovice & $50^{\circ} 43^{\prime}$ & $14^{\circ} 12^{\prime}$ & $26 / 09 / 04$ & 3 & $<1$ & AOPK \\
\hline Lužecký potok ( $\rightarrow$ Elbe, km 28$)$ & Povrly & $50^{\circ} 40^{\prime}$ & $14^{\circ} 10^{\prime}$ & $26 / 09 / 04$ & 3 & 2 & AOPK \\
\hline Luční potok $(\rightarrow$ Elbe, km 28$)$ & Malé Březno & $50^{\circ} 40^{\prime}$ & $14^{\circ} 10^{\prime}$ & $17 / 09 / 05$ & 4 & $<1$ & AOPK \\
\hline Modla $(\rightarrow$ Elbe, $\mathrm{km} 63)$ & Lovosice & $50^{\circ} 30^{\prime}$ & $14^{\circ} 04^{\prime}$ & $03 / 10 / 04$ & 4 & 2 & AOPK \\
\hline Ohře $(\rightarrow$ Elbe, $\mathrm{km} 65)$ & Bohušovice nad Ohři & $50^{\circ} 30^{\prime}$ & $14^{\circ} 09^{\prime}$ & 2004,2005 & 6 & 5 & ZD, AOPK \\
\hline Ohře & Doksany & $50^{\circ} 27^{\prime}$ & $14^{\circ} 09^{\prime}$ & 2003,2005 & 6 & 9 & $\mathrm{ZD}, \mathrm{AOPK}$ \\
\hline $\begin{array}{l}\text { Stará Ohře }(\rightarrow \text { Elbe, km } 67) \\
(\text { side channel of Ohře) }\end{array}$ & České Kopisty & $50^{\circ} 31^{\prime}$ & $14^{\circ} 10^{\prime}$ & $21 / 09 / 04$ & N/A & 1 & AOPK \\
\hline Pšovka ( $\rightarrow$ Elbe, km 107) & Mělník & $50^{\circ} 21^{\prime}$ & $14^{\circ} 30^{\prime}$ & 2002 & 3 & $<1$ & V03 \\
\hline Pšovka $^{+1}$ & Střemy & $50^{\circ} 23^{\prime}$ & $14^{\circ} 33^{\prime}$ & $1994-2005$ & 2 & $14-16$ & $\mathrm{~V} 03, \mathrm{~B} 06, \mathrm{AP}$ \\
\hline Pšovka: fishpond Velký rybník ${ }^{+1}$ & Střemy & $50^{\circ} 23^{\prime}$ & $14^{\circ} 33^{\prime}$ & $1994-2005$ & fishpond & $15^{*}$ & $\mathrm{~B} 06, \mathrm{ZD}, \mathrm{AP}$ \\
\hline $\begin{array}{l}\text { channel between fishpond Malý } \\
\text { Štampach and the Pšovka }{ }^{+1}\end{array}$ & Střemy & $50^{\circ} 24^{\prime}$ & $14^{\circ} 33^{\prime}$ & 2002 & $\mathrm{~N} / \mathrm{A}$ & N/A & V03, B06 \\
\hline $\begin{array}{l}\text { Vraňansko-hořínský channel } \\
\text { (connecting the Elbe, km } 109 \\
\text { and the Vltava, km 11.4) }\end{array}$ & Vrbno & $50^{\circ} 20^{\prime}$ & $14^{\circ} 27^{\prime}$ & 07/09/05 & $\mathrm{N} / \mathrm{A}$ & 2 & LB \\
\hline Vraňansko-hořínský channel & Lužec nad Vltavou & $50^{\circ} 20^{\prime}$ & $14^{\circ} 24^{\prime}$ & $13 / 09 / 05$ & $\mathrm{~N} / \mathrm{A}$ & 7 & LB \\
\hline Vraňansko-hořínský channel & Vraňany & $50^{\circ} 19^{\prime}$ & $14^{\circ} 22^{\prime}$ & $07 / 09 / 05$ & N/A & 10 & LB \\
\hline Jizera $(\rightarrow$ Elbe, $\mathrm{km} 141)$ & Nový Vestec & $50^{\circ} 11^{\prime}$ & $14^{\circ} 44^{\prime}$ & $22 / 05 / 04$ & 6 & 1 & ZD \\
\hline Vlkava ( $\rightarrow$ Elbe, km 159) & Kostomlaty nad Labem & $50^{\circ} 10^{\prime}$ & $14^{\circ} 56^{\prime}$ & $22 / 09 / 05$ & 4 & $<2$ & AOPK \\
\hline Výrovka ( $\rightarrow$ Elbe, km 163) & Písty & $50^{\circ} 10^{\prime}$ & $15^{\circ} 00^{\prime}$ & 2002 & 5 & $<2$ & CSOP \\
\hline Liduška ( $\rightarrow$ Elbe, km 166) & Nymburk & $50^{\circ} 10^{\prime}$ & $15^{\circ} 02^{\prime}$ & $22 / 09 / 05$ & 2 & $<1$ & AOPK \\
\hline Mrlina ( $\rightarrow$ Elbe, km 168) & Nymburk & $50^{\circ} 11^{\prime}$ & $15^{\circ} 04^{\prime}$ & 2002 & 6 & $<2$ & CSOP \\
\hline Cidlina $(\rightarrow$ Elbe, $\mathrm{km} 180)$ & Libice nad Cidlinou & $50^{\circ} 07^{\prime}$ & $15^{\circ} 11^{\prime}$ & $20 / 05 / 04$ & 6 & 2,5 & ZD \\
\hline $\begin{array}{l}\text { Bačovka }(\rightarrow \text { Elbe, km 182) } \\
\text { and surrounding dead arms }\end{array}$ & Velký Osek & $50^{\circ} 06^{\prime}$ & $15^{\circ} 11^{\prime}$ & $2002-4$ & 4 & 2,5 & $\begin{array}{l}\text { CSOP, } \\
\text { AOPK }\end{array}$ \\
\hline Doubrava ( $\rightarrow$ Elbe, $\mathrm{km} 203$ ) & Záboří nad Labem & $50^{\circ} 01^{\prime}$ & $15^{\circ} 21^{\prime}$ & $20 / 05 / 04$ & 6 & 1 & ZD \\
\hline Metuje ( $\rightarrow$ Elbe, km 287) & Jaroměř & $50^{\circ} 20^{\prime}$ & $15^{\circ} 55^{\prime}$ & $22 / 05 / 05$ & 6 & $<1^{*}$ & AOPK \\
\hline Úpa $(\rightarrow$ Elbe, km 289) & Jaroměř & $50^{\circ} 21^{\prime}$ & $15^{\circ} 56^{\prime}$ & $04 / 09 / 04$ & 6 & $<1^{*}$ & AOPK \\
\hline Úpa & Slatina nad Úpou & $50^{\circ} 27^{\prime}$ & $16^{\circ} 02^{\prime}$ & $04 / 09 / 04$ & 6 & $21^{*}$ & AOPK \\
\hline Úpa & Úpice & $50^{\circ} 30^{\prime}$ & $16^{\circ} 01^{\prime}$ & 2004 & 6 & $33^{*}$ & J. Špaček \\
\hline
\end{tabular}


Tableau II (continued)

\begin{tabular}{|c|c|c|c|c|c|c|c|}
\hline Watercourse / body & Nearest settlement & $\begin{array}{l}\text { Latitude } \\
\text { (N) }\end{array}$ & $\begin{array}{c}\text { Longitude } \\
\text { (E) }\end{array}$ & \begin{tabular}{|c|}
$\begin{array}{c}\text { Date of } \\
\text { observation }\end{array}$ \\
\end{tabular} & $\begin{array}{l}\text { Stream } \\
\text { order }\end{array}$ & $\begin{array}{l}\text { Distance from } \\
\text { mouth (km) }\end{array}$ & Source \\
\hline \multicolumn{8}{|c|}{ river VItava ( $\rightarrow$ Elbe, $\mathbf{k m}$ 109): most localities located in reservoirs (standing water) } \\
\hline VItava & Vrbno u Mělníka & $50^{\circ} 19^{\prime}$ & $14^{\circ} 27^{\prime}$ & $01 / 10 / 04$ & 8 & 5 & ZD \\
\hline Vltava & Klecany & $50^{\circ} 10^{\prime}$ & $14^{\circ} 24^{\prime}$ & 2001 & 8 & 37 & ZD \\
\hline Vltava & Praha - Suchdol & $50^{\circ} 08^{\prime}$ & $14^{\circ} 24^{\prime}$ & $26 / 08 / 05$ & 8 & 41 & LF \\
\hline $\begin{array}{l}\text { Vltava (reservoir Orlík, } \\
\text { confluence with Otava) }\end{array}$ & Zvíkovské Podhradí & $49^{\circ} 26^{\prime}$ & $14^{\circ} 12^{\prime}$ & $11 / 07 / 01$ & 8 & 169 & PK \\
\hline VIttava (reservoir Orlík) & Vůsí & $49^{\circ} 24^{\prime}$ & $14^{\circ} 15^{\prime}$ & $2001-4$ & 8 & 177 & PK \\
\hline VItava (reservoir Orlík) & Temešvár & $49^{\circ} 21^{\prime}$ & $14^{\circ} 16^{\prime}$ & $10 / 07 / 01$ & 8 & 182 & PK \\
\hline VItava (reservoir Orlík) & Strouhy & $49^{\circ} 20^{\prime}$ & $14^{\circ} 17^{\prime}$ & $15 / 07 / 03$ & 8 & 184 & PK \\
\hline Vltava (reservoir Orlík) & Jehnědno & $49^{\circ} 18^{\prime}$ & $14^{\circ} 20^{\prime}$ & $15 / 07 / 03$ & 8 & 191 & PK \\
\hline $\begin{array}{l}\text { VItava (reservoir Kořensko, } \\
\text { confluence with Lužnice) }\end{array}$ & Neznašov & $49^{\circ} 14^{\prime}$ & $14^{\circ} 23^{\prime}$ & $2001-4$ & 8 & 202 & PK, B05 \\
\hline Vltava & Týn nad Vltavou & $49^{\circ} 13^{\prime}$ & $14^{\circ} 25^{\prime}$ & $06 / 05 / 02$ & 7 & 205 & B05 \\
\hline VIttava (reservoir Hněvkovice) & Purkarec & $49^{\circ} 08^{\prime}$ & $14^{\circ} 27^{\prime}$ & 2001 & 7 & 217 & PK \\
\hline Vltava & Hluboká nad Vltavou & $49^{\circ} 03^{\prime}$ & $14^{\circ} 27^{\prime}$ & $30 / 08 / 04$ & 7 & 228 & AOPK \\
\hline Vltava (confluence with Malše) & České Budẽjovice & $48^{\circ} 58^{\prime}$ & $14^{\circ} 28^{\prime}$ & $12 / 09 / 05$ & $6-7$ & $240-241$ & AOPK \\
\hline \multicolumn{8}{|c|}{ tributaries in the watershed of Vltava: running waters } \\
\hline Sázava & Davle & $49^{\circ} 53^{\prime}$ & $14^{\circ} 24^{\prime}$ & $30 / 08 / 05$ & 7 & $<1$ & AOPK \\
\hline Sázava & Luka pod Medníkem & $49^{\circ} 52^{\prime}$ & $14^{\circ} 27^{\prime}$ & $30 / 08 / 05$ & 7 & 5 & AOPK \\
\hline $\begin{array}{l}\text { Janovický potok ( } \rightarrow \text { Sázava, } \\
\text { km 19; } \rightarrow \text { Vltava, km 78) }\end{array}$ & Krusičany & $49^{\circ} 48^{\prime}$ & $14^{\circ} 36^{\prime}$ & 2004 & 5 & $<1$ & V. Horálek \\
\hline $\begin{array}{l}\text { Vlkančický potok ( } \rightarrow \text { Sázava, } \\
\text { km 49; } \rightarrow \text { VItava, km 78) }\end{array}$ & Pyskočely & $49^{\circ} 53^{\prime}$ & $14^{\circ} 53^{\prime}$ & 2004 & 4 & 2 & V. Horálek \\
\hline Otava $(\rightarrow$ Vltava, km 169) & Zvíkovské Podhradí & $49^{\circ} 26^{\prime}$ & $14^{\circ} 12^{\prime}$ & $11 / 07 / 01$ & 7 & $<1$ & PK \\
\hline $\begin{array}{l}\text { Jickovický potok } \\
(\rightarrow \text { Vltava, } \mathrm{km} 171)\end{array}$ & Jickovice & $49^{\circ} 27^{\prime}$ & $14^{\circ} 13^{\prime}$ & $15 / 09 / 04$ & 2 & $<1$ & PK \\
\hline $\begin{array}{l}\text { Hrejkovický potok } \\
(\rightarrow \text { VItava, km 177) }\end{array}$ & Vůsí & $49^{\circ} 24^{\prime}$ & $14^{\circ} 16^{\prime}$ & $2001-5$ & 4 & $<1$ & PK \\
\hline Velký potok ( $\rightarrow$ Vltava, km 184) & Strouhy & $49^{\circ} 21^{\prime}$ & $14^{\circ} 18^{\prime}$ & $2001-5$ & 2 & $<1$ & PK \\
\hline $\begin{array}{l}\text { Novosedlský potok } \\
(\rightarrow \text { Vltava, km 184) }\end{array}$ & Strouhy & $49^{\circ} 21^{\prime}$ & $14^{\circ} 18^{\prime}$ & 05/09/04 & 2 & $<1$ & TP \\
\hline $\begin{array}{l}\text { Chř̌štovický potok } \\
(\rightarrow \text { Vltava, km 185) } \\
\end{array}$ & Chřeštovice & $49^{\circ} 20^{\prime}$ & $14^{\circ} 18^{\prime}$ & 05/09/04 & 2 & $<1$ & TP \\
\hline Lužnice $(\rightarrow$ Vltava, km 202) & Neznašov & $49^{\circ} 14^{\prime}$ & $14^{\circ} 24^{\prime}$ & $06 / 05 / 02$ & 7 & 1 & B05 \\
\hline $\begin{array}{l}\text { Bílinský potok ( } \rightarrow \text { Lužnice km 5; } \\
\rightarrow \text { Vltava, km 202) }\end{array}$ & Vesce & $49^{\circ} 16^{\prime}$ & $14^{\circ} 26^{\prime}$ & $14 / 10 / 04$ & 3 & $<1$ & $\mathrm{AP}$ \\
\hline Malše $(\rightarrow$ Vltava, km 240) & České Budějovice & $48^{\circ} 58^{\prime}$ & $14^{\circ} 29^{\prime}$ & $12 / 09 / 05$ & 6 & $<2$ & $\mathrm{PK}, \mathrm{AOPK}$ \\
\hline \multicolumn{8}{|c|}{ running waters not directly connected to main areas of Orconectes distribution } \\
\hline $\begin{array}{l}\text { Loupnice }^{+2}(\rightarrow \text { Bílina, km 56; } \\
\rightarrow \text { Elbe, } \mathrm{km} 39)\end{array}$ & Záluži (below the pond) & $50^{\circ} 33^{\prime}$ & $13^{\circ} 35^{\prime}$ & $23 / 10 / 04$ & 4 & $<1(57)$ & AOPK \\
\hline Loupnice $^{+2}$ & $\begin{array}{l}\text { Horni Jiřetín (below the } \\
\text { pond Vítěz) }\end{array}$ & $50^{\circ} 34^{\prime}$ & $13^{\circ} 34^{\prime}$ & $22 / 10 / 04$ & 3 & $3(59)$ & AOPK \\
\hline outflow from the quarry Barbora ${ }^{+3}$ & OIdřichov u Teplic & $50^{\circ} 38^{\prime}$ & $13^{\circ} 45^{\prime}$ & $16 / 07 / 03$ & 1 & $\begin{array}{c}<1 \text { (upstream) } \\
39 \text { (downstream) }\end{array}$ & ZD \\
\hline $\begin{array}{l}\text { artificial channel connecting water } \\
\text { bodies Kateřina and Modlany }{ }^{+4}\end{array}$ & Modlany & $50^{\circ} 39^{\prime}$ & $13^{\circ} 53^{\prime}$ & $25 / 09 / 05$ & N/A & $<1$ & AOPK \\
\hline $\begin{array}{l}\text { Drnecký potok }(\rightarrow \text { Šternberský p., } \\
\text { km } 4 ; \rightarrow \text { Červený, km 14; } \rightarrow \text { Ba- } \\
\text { kovský, km 10; } \rightarrow \text { Vltava, km 14) }\end{array}$ & Drnek & $50^{\circ} 12^{\prime}$ & $13^{\circ} 59^{\prime}$ & $21 / 08 / 05$ & 1 & $4(31) *$ & AOPK \\
\hline $\begin{array}{l}\text { Zlatá stoka }{ }^{+5} \text { (artificial channel } \\
\text { connecting fishponds) }\end{array}$ & Třeboň & $49^{\circ} 00^{\prime}$ & $14^{\circ} 46^{\prime}$ & 02/07/01 & N/A & N/A & PK \\
\hline \multicolumn{2}{|l|}{ other standing waters } & & & & \multicolumn{2}{|c|}{ character of the locality } & \\
\hline Klíčov (quarry "Na skále") & Mrákov & $49^{\circ} 24^{\prime}$ & $12^{\circ} 58^{\prime}$ & $2002-4$ & \multicolumn{2}{|c|}{ flooded quarry } & PK \\
\hline Kojetice & Kojetice u Neratovic & $50^{\circ} 14^{\prime}$ & $14^{\circ} 30^{\prime}$ & $2004-5$ & \multicolumn{2}{|c|}{ flooded quarry } & $\mathrm{AP}, \mathrm{LF}$ \\
\hline Černice $^{+2}$ & Černice & $50^{\circ} 34^{\prime}$ & $13^{\circ} 32^{\prime}$ & 2005 & \multicolumn{2}{|c|}{ undermined depression } & M. Holzer \\
\hline Barbora $^{+3}$ & Oldřichov u Teplic & $50^{\circ} 38^{\prime}$ & $13^{\circ} 45^{\prime}$ & $2003-5$ & \multicolumn{2}{|c|}{ flooded surface coalmine } & ZD, LF \\
\hline Kateřina $^{+4}$ & Soběchleby & $50^{\circ} 40^{\prime}$ & $13^{\circ} 54^{\prime}$ & $25 / 09 / 05$ & \multicolumn{2}{|c|}{ mining water reservoir } & AOPK \\
\hline Modlany ${ }^{+4}$ & Modlany & $50^{\circ} 39^{\prime}$ & $13^{\circ} 53^{\prime}$ & $30 / 09 / 05$ & \multicolumn{2}{|c|}{ mining water reservoir } & AOPK \\
\hline sandpit Lhota & Lhota & $50^{\circ} 15^{\prime}$ & $14^{\circ} 40^{\prime}$ & $2004-5$ & \multicolumn{2}{|c|}{ sandpit } & ZD, AP, LF \\
\hline sandpits Cítov & Vliněves & $50^{\circ} 22^{\prime}$ & $14^{\circ} 27^{\prime}$ & $2004-5$ & \multicolumn{2}{|l|}{ sandpit } & ZD, LF, LB \\
\hline sandpit Ovčáry & Ovčáry & $50^{\circ} 15^{\prime}$ & $14^{\circ} 37^{\prime}$ & $27 / 10 / 04$ & \multicolumn{2}{|l|}{ sandpit } & ZD \\
\hline Račice "channel" (rowing stadium) & Račice & $50^{\circ} 27^{\prime}$ & $14^{\circ} 21^{\prime}$ & 2004,2005 & \multicolumn{2}{|l|}{ sandpit } & ZD, AOPK \\
\hline Stará pískovna & Provodín & $50^{\circ} 37^{\prime}$ & $14^{\circ} 35^{\prime}$ & 13/09/04 & \multicolumn{2}{|l|}{ sandpit } & MS \\
\hline sandpit near the airport Borek & Stará Boleslav & $50^{\circ} 12^{\prime}$ & $14^{\circ} 40^{\prime}$ & $21 / 08 / 04$ & \multicolumn{2}{|l|}{ sandpit } & ZD \\
\hline Proboštský rybník + other sandpits & Stará Boleslav & $50^{\circ} 12^{\prime}$ & $14^{\circ} 39^{\prime}$ & $2004-5$ & sandpits & & ZD, LF \\
\hline sandpit Ostrá & Ostrá & $50^{\circ} 11^{\prime}$ & $14^{\circ} 54^{\prime}$ & $2001-2$ & sandpit con & nected to the Elbe & B05,CSOP \\
\hline sandpit Pišt'any & Piśštany & $50^{\circ} 32^{\prime}$ & $14^{\circ} 04^{\prime}$ & $14 / 09 / 05$ & sandpit cont & nected to the Elbe & AOPK \\
\hline village pond & Smečno & $50^{\circ} 11^{\prime}$ & $14^{\circ} 02^{\prime}$ & July 2005 & small pond & & AOPK \\
\hline pond in children camp & Střemy & $50^{\circ} 23^{\prime}$ & $14^{\circ} 33^{\prime}$ & $09 / 04 / 04$ & small pond & & $\mathrm{B} 06$ \\
\hline fishpond Štampach ${ }^{+1}$ & Střemy & $50^{\circ} 24^{\prime}$ & $14^{\circ} 33^{\prime}$ & $23 / 11 / 02$ & fishpond & & B06 \\
\hline fishpond Kocliřov ${ }^{+5}$ & Lomnice nad Lužnicí & $49^{\circ} 04^{\prime}$ & $14^{\circ} 41^{\prime}$ & October 2005 & fishpond & & LF \\
\hline fishpond by Říčanský potok & Praha - Dubeč & $50^{\circ} 03^{\prime}$ & $14^{\circ} 35^{\prime}$ & 2004 & fishpond & & AOPK \\
\hline
\end{tabular}


The presence of the spiny-cheek crayfish close to the mouth of most small streams, however, does not necessarily indicate a viable population, as the source population may be in the adjacent larger river or reservoir, and crayfish may penetrate to the small watercourse only temporarily. This is apparent from the fact that Orconectes has not been found in a number of small tributaries of the Elbe where historical records exist, but could be found in similar streams in close vicinity (Tab. I, II).

There are more discrepancies between older published distribution data of O. limosus and our present results. A study on the distribution of the species in Czechia in the 1990s (HAJER, 1994) reported the occurrence of this crayfish in middle or upper reaches of various rivers where it has not been confirmed after 2000 (most open circles in Figure 1). Moreover, Astacus astacus currently lives in one location (the river Ploučnice in the town Benešov nad Ploučnicí; $\left.50^{\circ} 44^{\prime} \mathrm{N}, 1^{\circ} 19^{\prime} \mathrm{E}\right)$ where Orconectes limosus had been reported in the 1990s. Similarly, the noble crayfish was found downstream of alleged O. limosus localities in the river Ohře. HAJER (1994) reported the spiny-cheek crayfish in the river Ohře from the town Litomerrice (at the confluence with the Elbe) to Žatec (88 km upstream from the Elbe). However, $A$. astacus was more recently found in Počedělice (44 km from the Elbe; ĎURIŠ, unpublished), and the presence of Orconectes was confirmed only downstream, in the village Doksany (9 $\mathrm{km}$ from the Elbe).

It is not clear whether the discrepancy of recent and older data has been caused by misidentification in the past, the downstream retreat of Orconectes, fragmentation of its populations during the last few years, or a reduction of Orconectes population density which subsequently prevented its detection. The combination of all these factors could play a role. For example, after extensive floods in 2002, the Orconectes density dropped considerably in the Elbe (ĎURIŠ et al., 2006; ŠPAČEK, pers. comm.) as well as in adjacent flooded sandpits and dead arms, and the floods may have similarly affected the crayfish populations in large rivers elsewhere. In at least some cases, however, the reports from the mid-1990s seem to be erroneous.

\section{CONCLUSIONS}

Orconectes limosus is the most widespread crayfish of non-European origin in the Czech Republic. It has occupied a large part of the Elbe watershed and due to humanmediated translocations, it can also be found in a number of isolated water bodies and some small streams. However, the monitoring of its distribution revealed that the species usually stays only in the lower reaches of smaller streams or rivers and that there are significant differences between the recent distribution and the historical data on its occurrence. The species is able to carry the crayfish plague pathogen and transmit it to native species. Therefore, it is important to monitor its invasion in the Czech Republic also in the future.

\section{ACKNOWLEDGEMENTS}

Our research of invasive crayfish was funded by the Czech Science Foundation (GAČR 206/03/0532 and 206/03/D064), Czech Ministry of Education (MSM0021620828 and MSM6007665809), Czech Ministry of Environment (VaV/620/01/03), and the Grant Agency of the Charles University (project GAUK 141/2005 B Bio). We would like to thank the "Hlávka" Foundation for financial support for attending the Craynet final meeting, J. Čtyroký for a valuable help with the GIS, and many colleagues, friends, and volunteers in the crayfish monitoring programs for the field data. Special thanks are to R. Samek from the Czech Union for Nature Conservation (ZO ČSOP Sluníčko) in Nymburk and L. Beran from the Protected Landscape Area Kokoŕínsko for unpublished data. We thank an anonymous referee for comments on the manuscript, and D. Hardekopf for language corrections. 


\section{REFERENCES}

BERAN L., 1995. Raci v CHKO Kokořínsko. [Crayfish in the Protected Landscape Area Kokořínsko.] Ochrana přírody, 50(4), 114-115. (in Czech)

BERAN L., 2003. Nálezy druhů Argyroneta aquatica (Araneida), Astacus astacus, Austropotamobius torrentium, Orconectes limosus (Decapoda) a Aphelocheirus aestivalis (Heteroptera) získané při průzkumu vodních měkkýšů v České republice. [Findings of Argyroneta aquatica (Araneida), Astacus astacus, Austropotamobius torrentium, Orconectes limosus (Decapoda) and Aphelocheirus aestivalis (Heteroptera) during the survey of aquatic molluscs in the Czech Republic.] Bulletin Lampetra, ZO ČSOP Vlašim, 5, 13-15. (in Czech)

BERAN L., in press. Crayfish (Decapoda; Crustacea) of the Kokořinsko PLA. Bohemia centralis, Praha, 28. (in Czech with English summary)

BUCHAR J., 1982. Způsob publikace lokalit živočichů z území Československa. [Publication of faunistic data from Czechoslovakia.] Věstník Československé společnosti zoologické, 46, 317-318. (in Czech)

ĎURIŠ Z., HORKÁ I., 2001. K výskytu raka bahenního Pontastacus (= Astacus) leptodactylus Eschscholtz na Karvinsku. [Occurrence of the narrow-clawed crayfish Pontastacus (= Astacus) leptodactylus Eschscholtz in vicinity of Karviná.] Časopis Slezského zemského muzea v Opavě (A), 50 (supl.), 78-84. (in Czech)

ĎURIŠ Z., DROZD P., HORKÁ I., KOZÁK P., POLICAR, T., 2006. Biometry and demography of the invasive crayfish Orconectes limosus in the Czech Republic. Bull. Fr. Pêche Piscic., 380-381, 1215-1228.

HAJER J., 1989. Americký druh raka v Labi. [An American species of crayfish in the river Elbe.] Živa, 37/75 (3), 125. (in Czech)

HAJER J., 1990. Stane se americký rak řiční trvalou součástí naší fauny? [Will the American crayfish become permament element of our fauna?] Fauna Bohemiae Septentrionalis, 14-15, 51-54. (in Czech)

HAJER J., 1994. Expanze raků druhu Cambarus affinis Say ve vodách České republiky. [Expansion of the crayfish Cambarus affinis Say in surface waters of the Czech Republic.] Fauna Bohemiae Septentrionalis, 19, 123-128. (in Czech)

HAMR P., 2002. Orconectes. In: Biology of freshwater crayfish. HOLDICH D.M. (Ed.), 585608. Blackwell Science, Oxford.

HENTTONEN P., HUNER J.V., 1999. The introduction of alien species of crayfish in Europe: A historical introduction. In: Crayfish in Europe as alien species. How to make the best of a bad situation? GHERARDI F., HOLDICH D.M. (Eds), 13-22. A.A. Balkema, Rotterdam, Brookfield.

HOLDICH D.M., 1999. The negative effects of established crayfish introductions. In: Crayfish in Europe as alien species. How to make the best of a bad situation? GHERARDI F., HOLDICH D.M. (Eds), 31-47. A.A. Balkema, Rotterdam, Brookfield.

HOLDICH D. M., 2003. Crayfish in Europe - an overview of taxonomy, legislation, distribution, and crayfish plague outbreaks. In: Management \& Conservation of Crayfish. Proceedings of a conference held on 7th November 2002 at the Nottingham Forest Football Club, Nottingham, UK. HOLDICH D. M., SIBLEY P. J. (Eds), 15-34. Environment Agency, Bristol, UK.

KOSSAKOWSKI J., 1966. Raki. [Crayfish.] Panstwowe wydawnictwo rolnicke i lesne, Warszawa. (in Polish)

KOZÁK P., ĎURIŠ Z., POLICAR T., 2002. The stone crayfish Austropotamobius torrentium (Schrank) in the Czech Republic. Bull. Fr. Pêche Piscic., 367, 707-713. 
KOZÁK P., POLICAR T., ĎURIŠ Z., 2004. Migratory ability of Orconectes limosus through a fishpass and notes on its occurrence in the Czech Republic. Bull. Fr. Pêche Piscic., 372-373, 367-373.

KOZUBíKOVÁ E., PETRUSEK A., ĎURIŠ Z., KOZÁK P., GEIGER S., HOFFMANN R., OIDTMANN B., 2006. The crayfish plague in the Czech Republic - Review of recent suspect cases and a pilot detection study. Bull. Fr. Pêche Piscic., 380-381, 1313-1324.

LINDQVIST O.V., HUNER J.V., 1999. Life history characteristics of crayfish: What makes some of them good colonizers? In: Crayfish in Europe as alien species. How to make the best of a bad situation? GHERARDI F., HOLDICH D.M. (Eds), 23-30. A.A. Balkema, Rotterdam, Brookfield.

MATĚNA J., 1995. Raci v České republice. [Crayfish in the Czech Republic.] Rybářství, 3, 72. (in Czech)

MATOUŠ H., 1995. Blaničtí rytiríi a labští zbojníci. ["Knigths of Blaník" and the "bandits of the Elbe river".] Rybářství, 9, 269. (in Czech)

NYLUND V., WESTMAN K., 2000. The prevalence of crayfish plague (Aphanomyces astaci) in two signal crayfish (Pacifastacus leniusculus) populations in Finland. Journal of Crustacean Biology, 20, 777-785.

PÖCKL M., 1999. Distribution of crayfish species in Austria with special reference to introduced species. Freshwater Crayfish, 12, 733-750.

PÖCKL M., PEKNY R., 2002. Interaction between native and alien species of crayfish in Austria: Case studies. Bull. Fr. Pêche Piscic., 367, 763-776.

POLICAR T., KOZÁK P., 2000. Výskyt raků v ČR. [Occurrence of crayfish in the Czech Republic.] Bulletin VÚRH JU, Vodňany, 1-2, 18-22. (in Czech)

PUKY M., 2000. Distribution of Decapoda species along the Hungarian Danube section and some tributaries with special emphasis on their conservation status. In: The Danube and its Tributaries: Antropogenic Impacts and Revitalisation. Limnologigal Reports. 285-290. Proceedings of the 33rd Conference of the International Association for Danube Research, 3-9 Sept. 2000, Osijek, Croatia.

PUKY M., REYNOLDS J.D., SCHÁD P., 2005. Native and alien Decapoda species in Hungary: distribution, status, conservation importance. Bull. Fr. Pêche Piscic., 376377, 553-568.

PUKY M., SCHÁD P., 2006. Orconectes limosus colonises new areas fast along the Danube in Hungary. Bull. Fr. Pêche Piscic., 380-381, 919-926.

STLOUKAL E., HARVÁNEKOVÁ M., 2005. Distribution of Austropotamobius torrentium (Decapoda: Astacidae) in Slovakia. Bull. Fr. Pêche Piscic., 376-377, 547-552.

VOGT G., 1999. Diseases of European freshwater crayfish, with particular emphasis on interspecific transmission of pathogens. In: Crayfish in Europe as alien species. How to make the best of a bad situation? GHERARDI F., HOLDICH D.M. (Eds), 87103. A.A. Balkema, Rotterdam, Brookfield.

VRZAL D., 2003. Biologické hodnocení jakosti vody v Pšovce s ohledem na výskyt raků. [Biological evaluation of water quality in Pšovka in respect to crayfish presence.] MSc. thesis, Faculty of Forestry, University of Agriculture, Prague. (in Czech) 
